\title{
A novel technique of migrated biliary stent retrieval
}

A 28-year-old man presented for stent removal one year after endoscopic retrograde cholangiogram and biliary stenting for anastomotic stricture after livingdonor liver transplantation. On duodenoscopy, two biliary stents were visible at the papilla, and retrieval was attempted with the aid of a snare. However, only one stent could be removed completely and the second biliary stent broke off and migrated proximally.

Subsequently, a guidewire was passed parallel to the migrated stent. Then a stone extraction balloon was passed over the guidewire in an attempt to retrieve the migrated stent by applying traction via the over-inflated balloon ( Fig.1). We could see the broken stent across the papilla upon traction. However, we could not exchange the balloon in the duodenoscope because the stent repeatedly migrated inwards once we deflated the balloon and attempted to exchange it for a snare.

In this scenario, we considered a doublechannel therapeutic scope (GIF-2TH180 EVIS EXERA II gastrovideoscope; Olympus, Tokyo, Japan) to retrieve the stent while simultaneously applying traction. To support insertion of the therapeutic scope, we initially placed a 5-Fr guide catheter (Boston Scientific, Marlborough, Massachusetts, USA) over the guidewire and the duodenoscope was exchanged for the therapeutic scope over the guide catheter. Once the therapeutic scope reached the papilla, the guide catheter was exchanged for a stone extraction balloon through one channel of the therapeutic scope and a snare loaded into the second channel. Then, by applying traction with the inflated balloon, the stent came across the papilla and the lower end of the stent was caught with the snare and successfully retrieved ( Video 1, > Fig. 2).

Various techniques have been described for retrieval of a migrated stent using forceps, a basket, snare, Soehendra stent
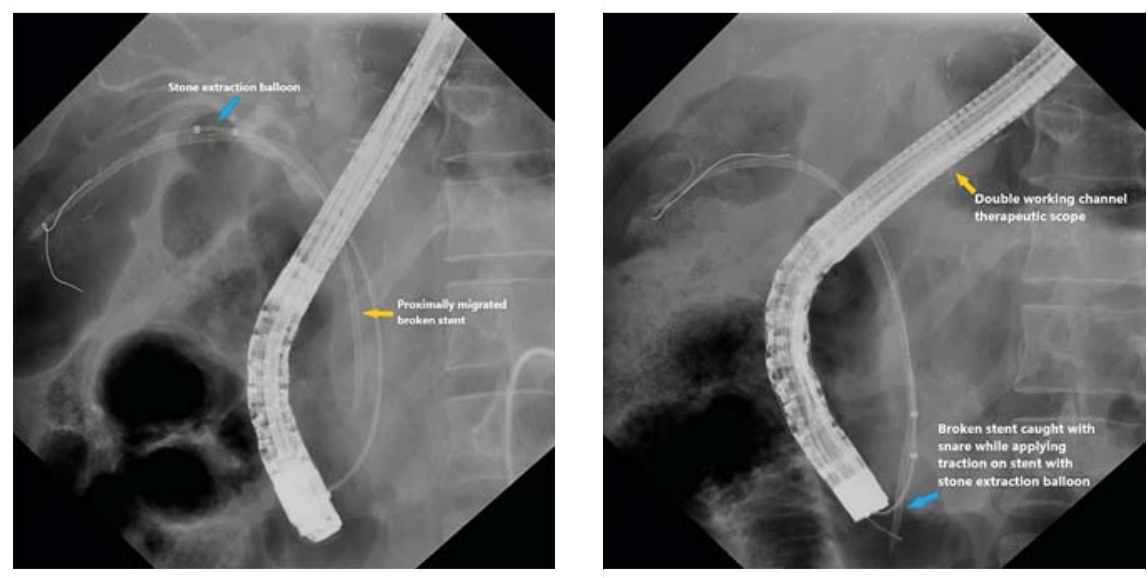

- Fig. 1 Fluoroscopy image during an endoscopic retrograde cholangiography showing broken, proximally migrated plastic stent (yellow arrow), along with inflated stone extraction balloon (blue arrow).
- Fig. 2 Fluoroscopy image showing the snare holding the broken stent with a stone extraction balloon applying traction (blue arrow) aided by a double-channel therapeutic endoscope (yellow arrow).

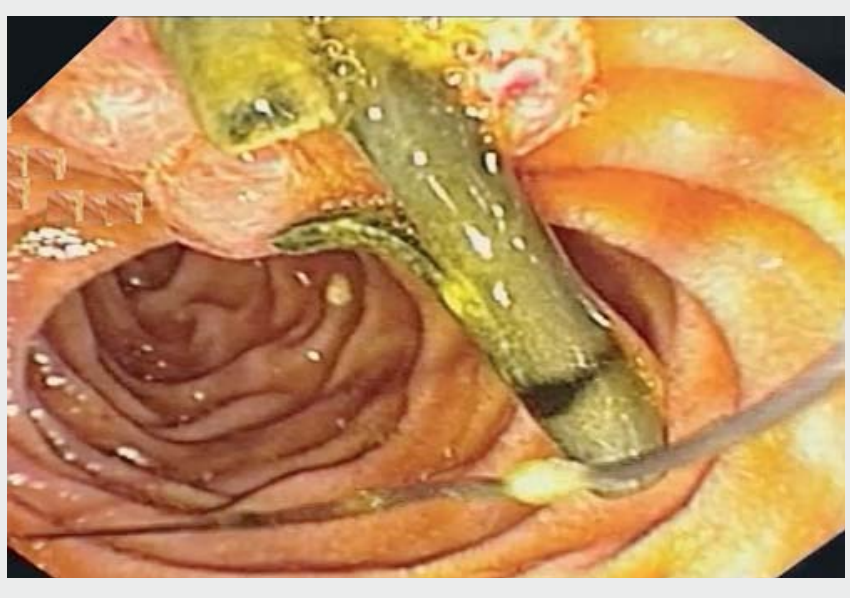

Video 1 Successful removal of a broken, proximally migrated plastic stent using a double-channel therapeutic endoscope along with a stone extraction balloon and snare in a patient with post-transplant biliary stricture.

retriever, cholangioscope, and balloon [1-4]. To the best of our knowledge, this is the first case that highlights the use of a therapeutic scope in stent retrieval.

Endoscopy_UCTN_Code_CPL_1AK_2AD

\section{Competing interests}

The authors declare that they have no conflict of interest. 
Rami Reddy Yalaka Chandan Kumar Kedarisetty, Santhosh M. Narayankar, Kondal Reddy Mogili, Manjunath T. Shepur, Sasanka Vangara

Department of Gastroenterology and Hepatology, Gleneagles Global Hospital, Hyderabad, India

\section{Corresponding author}

\section{Rami Reddy Yalaka, MD}

Department of Gastroenterology and Hepatology, Gleneagles Global Hospital, 6-1-1070/1-4, Lakdi-ka-pul, Hyderabad, 500004 , Telangana, India

yrrpgi@gmail.com
[1] Emara MH, Ahmed MH, Mohammed AS et al. Biliary stent migration: why, how, and what? Eur J Gastroenterol Hepatol 2021; 33: 967973

[2] Katsinelos P, Kountouras ], Paroutoglou G et al. Migration of plastic biliary stents and endoscopic retrieval: an experience of three referral centers. Surg Laparosc Endosc Percutan Tech 2009; 19: 217-221

[3] Ito T, Shimatani M, Naganuma M. Endoscopic retrieval of a migrated biliary stent into intrahepatic bile duct by using finegauge biliary balloon dilation catheter. Dig Endosc 2021; 33: e39-e40

[4] Al Lehibi A, Al Mtawa A, Almasoudi T et al. Removal of proximally migrated biliary stents by using single-operator. VideoGIE 2020; 5: 213-216
Bibliography

Endoscopy 2022; 54: E522-E523

DOI 10.1055/a-1662-3920

ISSN 0013-726X

published online 25.10 .2021

(C) 2021. Thieme. All rights reserved.

Georg Thieme Verlag KG, Rüdigerstraße 14,

70469 Stuttgart, Germany

\section{ENDOSCOPY E-VIDEOS}

https://eref.thieme.de/e-videos

回回 Endoscopy E-Videos is an open access online section, 回和: reporting on interesting cases and new techniques in gastroenterological endoscopy. All papers include a high quality video and all contributions are freely accessible online. Processing charges apply (currently EUR 375), discounts and wavers acc. to HINARI are available.

This section has its own submission website at

https://mc.manuscriptcentral.com/e-videos 